\title{
Basis on PMI of Corporate Bond Spreads Research
}

\author{
Jiemin Huang \\ Shenzhen Institute of Information Technology, 2188 Longxiang Boulevard, Longgang District, \\ Shenzhen City, People's Republic of China, 086-518172 \\ huang_jiemin819@126.com
}

Keywords: Corporate bond; Spread; Determinants

\begin{abstract}
This chapter analyzes the theoretical basis of the relevant papers. First, the meaning and connotation of corporate bond yield spreads to define the difference between corporate bonds and corporate bonds; secondly, analyzes the determinants of corporate bond yield spreads. Chinese corporate bonds and the existence of two kinds of corporate bonds credit bonds. About China's bond market, corporate bonds and corporate bonds, there are three different views, some people think corporate bonds and US municipal bonds is similar to the same corporate bonds with Europe and the United States corporate bonds; some people think that corporate bonds include corporate bonds and state-owned enterprises issue project bonds; Some people believe that they are different, but also corporate bonds included in corporate bonds, which is relativistic thinking.
\end{abstract}

\section{Corporate Bond Yield Spreads}

Connotation of Corporate Bonds. In fact, they are different in the following aspects, one, many corporate bonds guaranteed bonds issued by local governments, such as the city to vote bonds and the like. Second, corporate bonds to raise funds according to project needs, different European and American corporate bonds. Third, from a regulatory point of view and bonds, corporate bonds and project construction is closely related to corporate bonds issued by the Development and Reform Commission for review. And by the SFC approved the issuance of corporate bonds, exchange-market transactions.

Corporate bond research object for the Shanghai Stock Exchange and Shenzhen stock exchanges, via the Commission approved the issuance of these bonds, issuers of listed companies. The bonds are mostly short and medium term. Bond credit rating is relatively high. Issuers widely distributed range of industries, covering almost all sectors, with a certain representation.

Connotation of Yield Spreads. Corporate bond yields and spreads early by many scholars as credit spreads, it is assumed that risk-free government bonds and corporate bonds yield to maturity higher than the same period some of the risk-free government bonds yield to maturity. Investors face is mainly credit risk, corporate bond yield spread to some extent reflects the size of the company's credit risk profile.

Early scholars mining corporate bond yield spreads measure the size of the company's credit risk, while investors expected loss is the main measure of credit risk. Therefore, in this assumption, the expected loss should be equal in value to corporate bond yield spreads. But recently, some scholars empirical analysis found that the expected loss than the corporate bond yield spread is much smaller. The shorter the term of the bond, the higher the credit rating, expected loss accounts for corporate bond yield spreads smaller proportion.

This article will be expected inflation, exchange rates, the broad money supply, GDP growth rate, idiosyncratic volatility, liquidity risk, tax, risk and other risks caused by the system, the same release period, the same expiration date of the company's stocks and bond yields It is defined as the spread between corporate bond yield spreads (corporate bond spread). It is the object of study, hereinafter referred to as the yield spread, or spread or risk premium.

\section{Corporate bond spreads Determinants}

Macroeconomic Factors. Gross Domestic Product Growth (GDP) and the Purchasing Managers 
Index (PMI). Black, Kirkwood and Williams (2013) analyzed the Australian corporate bonds, considered in the analysis of GDP growth (GDP) and other macroeconomic factors [1]. Raedels (1990) found that the use Purchasing Managers Index (PMI) macroeconomic forecast ahead of other predictors seven months [2]. Kauffman (1999) purchasing managers index (PMI) index systematic and comprehensive analysis, and proved Purchasing Managers' Index (PMI) leading indicators of other indicators six month forecast of economic development situation changes [3]. Recently, Lindsey and Pavur (2005) attempt to predict the purchasing managers index knee (PMI) indicators, they analyzed the samples for a longer time, and proposed using regression analysis Purchasing Managers' Index (PMI) of inflection, and their research methods carter and Ellram's (2003) similar [4-5]. Larrain (2007) regression and neural network prediction Purchasing Managers' Index (PMI), results showed that short-term interest rates can be predicted 10 months Purchasing Managers' Index (PMI) changes, the article focused on the purchasing managers' index (PMI) as a predictor of . Among the many variables, the Purchasing Managers' Index (PMI) can be a good predictor of the real inventory, purchasing managers showed index (PMI) can predict changes in the inventory eight months [6].

Scholars from the analysis showed that gross domestic product growth (GDP) and the Purchasing Managers Index (PMI) are macroeconomic development in an important predictor, but the Purchasing Managers' Index (PMI) has forecast more timeliness. Some foreign scholars have used GDP growth (GDP) as macroeconomic indicators, analyzing the effect of corporate bond yield spreads. Based on the study on the basis of foreign scholars, representatives select both indicators of macroeconomic factors.

Rates. Clare et al. (2000) analysis found that if the US dollar real exchange rate, the euro will have a positive bond spreads [7]. KatiusciaManzoni (2002) using the mark against the pound sterling represents appreciation or depreciation, he believes that if the appreciation of sterling, the overseas issuer to repay credit debt increase, so credit spreads increase [8]. JAHJAH (2013) analyzed the impact of exchange rate policies on developing countries bonds, he found that a fixed exchange rate of national bonds they issue a higher interest rate [9].

Based on the above analysis, this paper against the dollar as one of the factors of macroeconomic indicators, based on the above analysis, if the RMB against the US dollar exchange rate, the devaluation of the yuan outside, in favor of export-dependent manufacturing business development, corporate bond yields, the interest rate differential relatively lower. This paper will analyze the impact on the corporate bond yield spreads.

The Broad Money Supply (M2). Alessandrini (1999), Huang and Chen (2007) found that monetary policy is an important determinant of corporate bond yield spreads [10-11]. Beckworth, Moon, Toles (2010) with long-term monetary vector autoregression method for neutral conditions to verify the impact of monetary policy on corporate bond yield spread default risk, liquidity risk and risk aversion affected. He found that the impact of monetary policy can indeed explain the corporate bond yield spread in large part. Studies suggest that the impact of monetary policy by influencing the default risk, risk aversion and liquidity premium to influence corporate bond yield spreads, monetary policy and the impact of corporate bond yield spreads reverse change [12].

These studies show that when the government implemented loose monetary policy, namely to increase the broad money supply (M2), the favorable economic environment, enterprises are facing bankruptcy risk of default is reduced, on the contrary, increase. According to research scholars, this paper this variable as an important macroeconomic indicators, analyzing the effect of corporate bond yield spreads.

Consumer Price Index. Sun Ke (2010) will be the consumer price index (CPI) is one of macroeconomic factors, with inflation showing it, analyze its impact on corporate bond credit spreads, inflation is found that one of the important factors [13].

In this paper, scholars, based on the consumer price index (CPI) inflation as a factor, it would be as macroeconomic factors, to measure its impact on corporate bond yield spreads.

PPI. He Liping, Fan et al. (2008) in the consumer price index and producer price index: Who's who led a joint paper analyzes the relationship between the producer price index (ppi) and the 
consumer price index between the industrial price index? As an important measure of macroeconomic indicators [14].

When the producer price index (ppi) rises, the industrial enterprises in related industries chain costs rise, companies face increased risk, so the company default probability increase.

In this paper will be the basis of the literature of industrial price index (ppi) as an important indicator of macroeconomic analysis of its impact on corporate bond yield spreads.

Corporate Goods Trading Price Index. Zhang Chengsi (2010) in the long-run equilibrium price and monetary Forced driving --- a research paper in the corporate goods price index trading (cgpi) on the middle and lower price transmission mechanism as the middle part of price transmission mechanism, which represents companies wholesale products reproduction of the price level, analysis of the impact on prices, currency macroeconomic [15].

When the corporate goods price index trading (cgpi) rise, upstream firms increased costs will increase Forced whole industry chain costs, companies face increased risk, thus increasing corporate bond yields. This paper will analyze the influence of corporate goods price index trading (cgpi) corporate bond yield spreads.

Industrial Sales Output Value and Industrial Added Value. In this paper will be the basis of its research and industrial sales output value of industrial added value as arguments, they are an important indicator of macroeconomic factors, analyze its impact on corporate bond yield spreads. Because the industrial sales output value and industrial added value increased, said the economy in good condition and reduce the probability of bankruptcy, thus reducing the corporate bond yield spread.

\section{Reference}

[1] Black S., Joshua K., Williams T. A history of Australian corporate bonds [J]. Australian Economic History Review, 2013, 53(3): 292-317.

[2] Raedels A. Forecasting the MAPM Purchasing Managers' Index [J]. Journal of Supply Chain Management, 1990, (15): 34-39.

[3] Kauffman R.G. Indicator Qualities of the NAPM Report On Businesss [J]. The Journal of Supply Chain Management, 1999, (35): 29-37.

[4] Lindsey M.D., Pavur R.J. As the PMI Turns: A Tool for Supply Chain Managers [J]. Journal of Supply Chain Management, 2005, (1): 30-39.

[5] Carter C.R., Ellram L.M. Thirty-five Years of the Journal of Supply Chain Management: Where HaveWe Been and Where Are We Going?[J]. Journal of Supply Chain Management, 2003, 39(2): 27-39.

[6] Larrain M. The PMI, the T-Bill and Inventories: A Comparative Analysis of Neural Network and Regression Forecasts [J]. The Journal of Supply Chain Management, 2007, (1): 39-51.

[7] Clare AD, Oozeer MC, Priestley R, et al. Modeling the Risk Premium on Eurodollar Bonds [J]. The Journal of Fixed Income, 2000, 9: 61-73.

[8] Katiuscia M.Modeling Credit Spreads:An Application to the Sterling Eurobond Market[J]. International Review of Financial Analysis, 2002, 11: 183-218.

[9] Jahjah M. Exchange Rate Policy and Sovereign Bond Spreads in Developing Countries [J]. Journal of Money, Credit and Banking, 2013, 45(7): 1276-1300.

[10] Alessandrini F. Credit risk, interest rate risk, and the business cycle [J]. The Journal of Fixed Income, 1999, 9: 42-53.

[11] Huang Y, Chen C R. The effect of Fed monetary policy regimes on the US interest rate swap spreads [J]. Review of Financial Economics, 2007, 16: 375-99.

[12] Beckworth D, Moon K P, Toles J H. Monetary policy and corporate bond yield spreads [J]. 
Applied Economics Letters, 2010, 17: 1139-1144.

[13] Sun Ke, Corporate credit spreads research [J]. The influence factors of dynamic process of the securities market leader, 2010, 7:24 to 31 .

[14] Li-ping He, Fan Gang, Hu Jia Ni. The consumer price index and producer price index: who's driving? [J]. Journal of economic studies, 2008, 11:16-26.

[15] Zhang Chengsi. Long-term equilibrium, reversed transmission price and monetary drive - in the middle and lower reaches of the price transmission mechanism research in China [J]. Journal of economic studies, 2010, 6:42-52. 